\title{
Переработка куриного
}

\section{помета с использованием личинок черной львинки (Hermetia illucens): $0630 p$}

\begin{abstract}
Свергузова С.В., доктор технических наук, зав. кафедрой промышленной экологии ФГБОУ ВО «Белгородский государственный технологический университет им. В.Г. Шухова» (БелГТУ) Шайхиев И.Г., доктор технических наук, заведующий кафедрой инженерной экологии ФГБОУ ВО «Казанский национальный исследовательский технологический университет»
\end{abstract}

Сапронова Ж.А., доктор технических наук, профессор кафедры промышленной экологии Бомба И.В., ассистент кафедры промышленной экологии БелГТУ

\begin{abstract}
Аннотаиия: В обзоре кратко обобщены исследобания отечественных и зарубежных абторов по использованию личинок мухи черная львинка (Hermetia illucens L.) для переработки отходов птицеводства - куриного помета. Приведены данные по составу куриного помета и объемам его образования. Перечислень различные направления переработки и утилизации птичьего помета, 6 том числе и биоконберсия с использованием личинок различных насекомых. Показаны преимущества переработки помета кур с использованием личинок Н. illucens. Кратко описаны жизненный иикл разбития данного вида насекомых, который Включает несколько фаз, и химический состав взрослых личинок. Приведены сведения о составе птичьего помета, свиного и коровьего навоза, используемых 6 качестве субстратов для культивирования личинок насекомого. Указаны достоинства помета кур перед остальными отходами животноводства для выращивания личинок. Кратко приведень сведения по результатам культивирования личинок Н. іllисепs на указанных субстратах. Показано, что быращибание личинок насекомого способствует уменьшению количества антибиотиков, тяжелых металлов и патогенных микроорганизмов 6 биокомпосте и снижению эмиссии летучих соединений 6 боздушную среду. Биокомпост рекомендовано использовать 6 качестве удобрения для быращивания сельскохозяйственных культур; биомассу личинок можно использовать как бысокопротеиновую добавку $в$ рационах птицьл.
\end{abstract}

ключебые слоба: куриный помет, переработка, муха черная льбинка (Hermetia illucens), личинки, биоконверсия.

Птицеводство является одним из динамично развивающихся секторов животноводства в мировом масштабе. В недавнем прошлом (2016 г.) в мире, по оценкам специалистов, поголовье домашней птицы составляло более 23 млрд. голов [1]. Мировое производство яиц составляло в 2016 г. 73 млн. т, а производство мяса птицы в мире было близко к 100 млн. т [1]. По оценкам, в 2050 году численность населения мира достигнет 9,6 млрд. человек. Ожидается, что мясо птицы будет иметь самый высокий прирост объема производства - 121\%, а спрос на яйца может увеличиться на 65\% [2]. Положительная тенденция развития птицеводства в мире приведет к соответствующему увеличению объемов образующегося птичьего помета. Известно, что объем образования помета от молодняка яичных кур составляет 100 г/сутки, от молодняка мясных кур - 110 г/сутки, от взрослых кур - 155 г/сутки [3], а общее количество образующегося помета с влажностью 70\% от одной кури- цы, с учетом срока продуктивного использования кур-несушек 460 дней [4], составляет 50-60 кг [5].

Птичий помет - продукт выделения птиц, серо-зеленый комковатый коллоидный субстрат, содержащий от 30 до 80\% органического вещества. Помет является источником выделения ядовитых газов - $\mathrm{NH}_{3}, \mathrm{H}_{2} \mathrm{~S}, \mathrm{CH}_{4}$, CO, загрязняющих атмосферу и неблагоприятно влияющих на состояние озонового слоя. В свежем помете, как правило, в значительном количестве содержатся яйца гель- 
минтов, он является благоприятной средой для развития патогенных микроорганизмов [4]. По данным Всемирной организации здравоохранения, более 100 видов различных возбудителей болезней животных и человека могут успешно развиваться в этой среде. В помете также содержатся медикаменты, используемые для дезинфекции птичников. Внесение в почву помета без предварительного карантирования и переработки не разрешается. Известно, что при попадании в почву свежего помета возбудитель сальмонеллеза сохраняет жизнеспособность до 5 месяцев, туберкулеза - до 17 месяцев. Почва при внесении такого помета в значительной степени обсеменяется микрофллорой, что создает экологическую и санитарную опасность. По Федеральному классификационному каталогу отходов (ФККО), свежий куриный помет относится к 3 классу опасности, а перепревший - к 4 классу опасности; однако при этом он является ценным органическим удобрением, содержащим все необходимые питательные вещества для роста и развития растений [4].

Отличительной чертой куриного помета является повышен- ное, по сравнению с навозом крупного рогатого скота и свиней $[6,7]$, содержание биогенных элементов (табл. 1).

В работе [11] приведен химический состав подстилочного куриного помета, образующегося на ОАО «Витебская бройлерная птицефабрика», в котором содержание элементов колеблется в следующих интервалах (кг/т): общий азот - от 6,2 до 18,6; $\mathrm{P}_{2} \mathrm{O}_{5}$ - от 7,0 до 14,3; $\mathrm{K}_{2} \mathrm{O}$ - от 5,8 до 19,6; $\mathrm{CaO}$ - от 5,8 до 10,7; MgO - от 5,2 до 12,60. Содержание тяжелых металлов также изменяется в широких пределах (г/т): Zn - от 129,4 до 569,4; Cu - от 43,3 до 99, 1 ; Mn - от 109,7 до 434,6; $\mathrm{Pb}$ - от 4,2 до 19,7; Cd - от 0,0 до 0,14.

В настоящее время существуют различные направления переработки и утилизации птичьего помета [5,12]: прямое внесение в почву без дополнительной обработки [13]; компостирование [14]; вермикомпостирование [15]; обезвоживание, сушка и гранулирование [16,17]; пиролиз при 450-550ㄷ $[18,19]$; плазменная газификация [20]; термическая деполимеризация [21]; прямое сжигание в паровых и водогрейных котлах [22]; микробиологическая конверсия [23]. Кроме указанных выше технологических способов переработки куриного помета, также упоминается биоконверсионный способ его переработки с помощью личинок домашней мухи (Musca domestica L.) [5,24]. Данное направление - использование личинок насекомых для переработки различных органических субстратов, в том числе и органических отходов производств - в настоящее время интенсивно изучается и развивается в мировом сообществе.

Однако, как показывает анализ литературных источников, более перспективными для выращивания на органических субстратах являются личинки мухи вида черная львинка (Hermetia illucens L.) - насекомого из семейства львинок (Stratiomyidae) отряда двукрылых (Diptera). Природный ареал насекомого - тропические, субтропические и теплые умеренные зоны Северной и Южной Америк. В последние десятилетия насекомое занесено и адаптировано человеком на все обитаемые континенты.

Жизненный цикл развития данного вида включает несколько фаз. Взрослые особи мух спариваются на третий день жизни после вылупления из куколок, и

\begin{tabular}{|c|c|c|c|c|}
\hline \multirow[t]{2}{*}{ Химический элемент } & \multicolumn{4}{|c|}{ Содержание (\%), согласно литературному источнику: } \\
\hline & [7] & [8] & [9] & [10] \\
\hline $\mathrm{N}$ & 2,40 & $3,93-7,11$ & 6,7 & 3,72 \\
\hline $\mathrm{P}$ & 2,43 & $0,03-1,51$ & 2,06 & 1,89 \\
\hline $\mathrm{K}$ & 2,44 & н.д. & 1,66 & 2,03 \\
\hline $\mathrm{Ca}$ & 14,0 & $3,44-5,56$ & 3,2 & 2,71 \\
\hline $\mathrm{Na}$ & 0,58 & $1,96-2,72$ & н.д. & н.д. \\
\hline $\mathrm{Mg}$ & 0,56 & $0,32-0,77$ & 0,29 & 0,49 \\
\hline $\mathrm{Zn}$ & 0,04 & $0,02-0,03$ & 0,09 & \\
\hline $\mathrm{Fe}$ & 0,19 & н.д. & 0,046 & н.д. \\
\hline $\mathrm{Cu}$ & $\mathrm{H} / \mathrm{O}$ & н.д. & 0,002 & н.д. \\
\hline $\mathrm{Mn}$ & 0,05 & $0,02-0,03$ & 0,089 & н.д. \\
\hline$S$ & 0,86 & $0,016-0,357$ & 0,31 & н.д. \\
\hline B & $\mathrm{H} / \mathrm{O}$ & н.д. & 0,06 & н.д. \\
\hline
\end{tabular}

Примечание: н/о - не обнаружено, н.д. - нет данных. 


\begin{tabular}{|c|c|c|c|c|}
\hline \multirow{2}{*}{ Компонент } & \multicolumn{4}{|c|}{ Содержание, \% } \\
\hline & птичий помет & коровий навоз & Свиной навоз & конский навоз \\
\hline Влажность & $76,06[39]$ & 76,08 [39] & $72,4[42]$ & \\
\hline Сырой протеин & $\begin{array}{c}28,91[39] ; \\
371 \text { г/кг СВ [41] }\end{array}$ & $20,18[39]$ & $\begin{array}{c}60 \text { [39]; } \\
74,5 \text { г/кг CB [41] }\end{array}$ & 371 г/кг СВ [43] \\
\hline Жирные кислоты & $4,37[39]$ & $2,04[39]$ & 20 г/кг СВ [41] & 12,0 г/кг СВ [43] \\
\hline Целлюлоза & $\begin{array}{l}14,38[39], \\
14,49[40]\end{array}$ & $\begin{array}{l}26,85[51] ; \\
31,71[40]\end{array}$ & 298 г/кг СВ [41] & 372 г/кг СВ [43] \\
\hline Гемицеллюлоза & $\begin{array}{l}20,48 \text { [39]; } \\
21,66[40]\end{array}$ & $\begin{array}{l}\text { 14,71 [51]; } \\
16,79[40]\end{array}$ & & \\
\hline Лигнин & $\begin{array}{l}4,54[51] ; \\
7,83[40]\end{array}$ & $\begin{array}{l}15,51[51] ; \\
13,58[40]\end{array}$ & & \\
\hline Углерод & $40,19[40]$ & $46,36[40]$ & & \\
\hline Общий азот & $2,14[40]$ & $2,14[40]$ & $0,45[42]$ & 14,78 г/кг СВ [43] \\
\hline Фосфор & $2,28[40]$ & $0,67[40]$ & $0,19[42]$ & \\
\hline Соотношение $\mathrm{C} / \mathrm{N}$ & $15,69[40]$ & $21,77[40]$ & & $27,13[43]$ \\
\hline
\end{tabular}

уже через несколько дней самка откладывает от 600 до 1000 яичек во влажный органический субстрат. В качестве последнего возможно использовать навоз домашних животных [25,26], различные пищевые отходы [27,28], отходы от переработки сельскохозяйственного сырья [29,30], пивоварения [31] и др. Через несколько дней из яичек вылупляются личинки насекомого длиной до 5 мм, которые развиваются в течение 14-20 дней, в зависимости от параметров окружающей среды. За названный отрезок времени личинки усиленно усваивают органический субстрат, наращивая свою биомассу и увеличивая свои размеры до 30 мм в длину и до 6 мм в ширину. Многочисленными исследованиями установлено, что личинки H. illucens могут утилизировать более 50\% органического субстрата, на котором они развиваются, превращая его в ценное органическое удобрение [32]. Когда личинки достигают финальной стадии развития, они превращаются в предкуколок, последние окукливаются, из них впоследствии выводятся взрослые особи мух, и жизненный цикл насекомого повторяется.

Отличительной чертой личинок H. illucens является их со- став, состоящий из сырого белка, насыщенных и ненасыщенных жирных кислот, хитина и др. Указывается, что сухое вещество личинок на $32-40 \%$ состоит из белков и на 13-42\% - из жиров, в зависимости от субстрата, на котором они развивались [33,34]. В составе белков личинок H. illucens содержатся такие аминокислоты, как аргинин, гистидин, лейцин и изолейцин, лизин, фенилаланин, тирозин, валин и др. [35], а также такие кислоты, как лауриловая, миристиновая, пальмитиновая, стеариновая, олеиновая, линолевая, линолеиновая и др. [36]. Указывается, что личинки $H$. illucens содержат в своем составе витамин Е и некоторые минеральные соединения [37]. Точный состав макро- и микроэлементов в личинках может быть изменен путем изменения состава субстрата, на котором они развиваются.

Данное обстоятельство делает высушенную биомассу личинок H. illucens весьма питательной, способной заменить, в частности, рыбную и соевую муку при кормлении и выращивании рыб в аквакультуре, домашних птиц и животных.

В настоящем обзоре обобщены литературные сведения о биоконверсии куриного помета личинками H. illucens [38-68]. Анализ литературных источников показал, что куриный помет отличается от навоза домашних животных, также применяемого в качестве субстрата для выращивания личинок черной львинки, более высоким содержанием сырого протеина и жирных кислот и меньшим содержанием клетчатки (табл. 2).

Сравнением показатели биоконверсии личинками $H$. illucens свиного навоза и птичьей пометной подстилки, в частности, выявлено, что продолжительность переработки этих субстратов составили 10 и 25 суток, конверсия субстрата - 40,5 и 41\%, а средняя масса личинок достигала 144 и 100 мг соответственно этим субстратам. Определено также, что содержание протеина в личинках, выращенных на свином навозе и птичьей пометной подстилке, составляло 42,77 и 40,38\%, а содержание жиров - 22,33 и $22,11 \%$ соответственно [41].

В то же время, в работе [44] указывается, что личинки H. illucens до стадии куколок развиваются на свином навозе в течение 36 сут., а на курином помете - в течение 26 сут. В противоположность данным, полученным в работе [41], 
личинки черной львинки, выросшие на курином помете, имели среднюю массу 223 мг, а на свином навозе - 200 мг. Выявлено, что содержание жирных кислот в составе предкуколок насекомого, выросших на помете кур, составило $32,7 \%$, на навозе свиней - 22,97\% [44].

В исследовании [45] личинки Н. illucens выращивались на трех субстратах: кухонные отходы, куриный помет и свиной навоз. Норма подачи субстрата составляла от 100 до 220 мг в расчете на 1 личинку в день. Во всех случаях личинки насекомого, которые выращивались на помете кур, имели наибольшую массу - от 70 до 200 мг в зависимости от количества субстрата, на свином навозе - от 65 до 175 мг, на кухонных отходах - от 62 до 108 мг. Кроме того, выявлено, что при применении куриного помета наблюдался самый высокий уровень биоконверсии (10,5\%), а самый низкий $(5,5 \%)$ - при использовании кухонных отходов. В то же время, самый высокий коэффициент конверсии корма был зарегистрирован в случае, когда в качестве субстрата применялся свиной навоз $(8,7)$, а самый низкий $(6,7)$ - кухонные отходы. Что касается сокращения отходов, самая высокая степень $(75,7 \%)$ зафиксирована для куриного помета, а самая низкая $(53,7 \%)$ - для кухонных отходов.

В то же время, сообщалось, что скорость прироста биомассы предкуколок H. illucens была наибольшей при выращивании на пищевых отходах, а изученные субстраты по этому параметру расположились в следующий ряд: пищевые отходы > свиной навоз > птичий помет > коровий навоз. В этом исследовании также было установлено, что максимальное содержание сырого жира $(372,4$ г/кг) и белка $(436,9$ г/кг) наблюдалось у личинок насекомого, выращенных на пищевых отходах [46].

Как следует из приведенных выше данных, наименьшая скорость прироста биомассы личинок черной львинки наблюдается при использовании коровьего навоза. Данное обстоятельство вызвано высоким содержанием целлюлозы, гемицеллюлозы и лигнина в этом виде навоза. В частности, указывается, что чем меньше содержание клетчатки в кормовом субстрате и ниже температура разогрева массы, тем легче перевариваются и усваиваются личинками $H$. illucens компоненты субстрата, тем короче продолжительность периода биоконверсии, и тем выше накопление биомассы личинок. Т.е. лимитирующим фактором развития личинок является содержание клетчатки в субстрате, превышающее 7\% [41]. Выявлено, что при смешении 40\% коровьего навоза с 60\% куриного помета значительно увеличилась конверсия целлюлозы - до $61,19 \%$, гемицеллюлозы - до $53,22 \%$ и лигнина - до 42,23\% по сравнению с аналогичными показателями $(49,89 ; 49,77$ и $31,95 \%)$ для чистого коровьего навоза [40].

Также сообщалось, что добавление к куриной пометной подстилке свекловичного жома в количестве $10 \%$ позволило увеличить степень конверсии субстрата с 41,0 до 47,5\% через 14 дней культивации личинок черной львинки. Указывается, что из 1 кг влажного смесевого субстрата возможно получить до 400 г сырой биомассы личинок насекомого, в которой протеина не менее 35\% по абсолютно сухому веществу [47].

Кроме того, выявлено, что добавление в смесевой субстрат, на котором развиваются личинки H. illucens, штаммов микроорганизмов рода Bacillus способствует достижению выживаемости личинок насекомого выше 99\%, времени развития 19 дней, степени сокращения объемов навоза 48,7\%, степени биоконверсии $10,8 \%$ и средней массы личинок 112,5 мг. В контроле последний показатель составил 90 мг [39].

Куриный помет подвергался переработке с использованием личинок черной львинки и бактерий вида B. subtilis. C 1000 кг помета кур, инокулированного штаммом данных бактерий, собрано 93,2 кг личинок, в то время как в контрольной группе собрано 80,4 кг. Найдено, что степень конверсии помета, содержащего бактерии B. subtilis, coставила 40,5\%, а без них - 35,8\%. Кроме того, выявлено, что масса личинок в опытной группе увеличилась на 15,9\%, коэффициент конверсии и коэффициент уменьшения объемов куриного помета - на 12,7 и 13,4\% соответственно по сравнению с контрольной группой [48].

В другом исследовании куриный помет предварительно инокулировали штаммами B. subtilis, выделенным из кишечника личинок черной львинки, и B. natto, выделенным из корма, на котором выращиваются эти же личинки. Предварительно ферментированный субстрат далее засевался 4-дневными личинками $H$. illucens. Определено, что средняя масса личинок насекомого, выросших на ферментированном субстрате, составила 94,6 мг, на интактном помете - 60,6 мг; длина тела взрослых насекомых, полученных от личинок в опытных группах, также была достоверно больше, чем в контроле [49].

Выделенные из яичек мухи и кишечника личинок $H$. illucens 
бактерии были инокулированы в птичьем помете совместно с личинками вышеназванного вида насекомого. Установлено, что большая часть симбионтных бактерий способствуют росту личинокчерной львинки. Определено, что наибольшую массу по сравнению с контрольной группой имели личинки, выращиваемые на субстрате, в который вносились штаммы видов Kocuria marina, Lysinibacillus boronitolerans, Proteus mirabilis и B. subtilis [50]. Наибольшее увеличение массы личинок (на 28,6\%) и снижение массы субстрата $(52,9 \%)$, а также содержание протеинов и жирных кислот в личинках наблюдались в случаях, когда названные микроорганизмы вносились в субстрат совместно в определенных пропорциях [50,51]. Сделан вывод, что инокуляция предварительно ферментированного куриного помета различными штаммами микроорганизмов позволяет значительно увеличить массу предкуколок и куколок $H$. illucens, сократить время для достижения стадии предкуколки, и значительно увеличить количество и длину тела взрослых насекомых [52].

Таким образом, можно считать установленным, что процесс совместной конверсии с использованием симбионтных бактерий и личинок черной львинки может сократить время обработки куриного помета по сравнению с традиционным процессом компостирования. Кишечные бактерии, инокулированные в субстрат, могут повысить степень конверсии помета и способствуют увеличению массы личинок насекомого [39, 48-52].

Исследована композиция, состоящая из куриного помета (34,5\%), воды (58,3\%) и шабазита, природного минерала из группы цеолитов грубого помола (7,2\%), для выращивания личинок черной львинки. Выявлено, что культивирование личинок приводит к снижению исходного количества субстрата более чем на 75\%, при этом средняя масса выращенных предкуколок составила 90 мг, а степень их выживания - 86\% [53].

Кроме того, сообщалось, что на степень биоконверсии куриного помета личинками H. illucens, влияет регион происхождения последних. Так, личинкам черной львинки происхождением из Уханя (Китай) требовалось на 29,9\% меньше времени, чтобы достичь стадии предкуколки при выращивании на курином помете, чем личинкам из Гуанчжоу (Китай) или Техаса (США). Также личинки насекомого из Уханя имели массу на 37,0\% больше, чем из других регионов. Личинки H. illucens из Уханя снижали содержание сухого вещества в субстрате на 48,4\% больше, чем личинки из Гуанчжоу и на 7,9\% - чем из Техаса [54].

Биоконверсия куриного помета с использованием личинок $H$. illucens способствует не только уменьшению объема субстрата, но и снижению содержания в нем патогенных микроорганизмов [55]. В частности, сообщалось, что культивирование личинок на помете кур способствует снижению содержания в нем таких патогенов, как Escherichia coli 01 57:H7 и Salmonella enterica [56]. Выявлено, что уменьшение количества E. coli 0157:H7 в курином помете зависит от температуры хранения: наибольшая степень снижения количества этих микроорганизмов наблюдается при температурах выше $27^{\circ} \mathrm{C}$ [56].

Также определено, что культивирование личинок черной львинки способствует снижению концентрации антибиотиков в субстрате за 12 дней на 95,0\%; при обычном компостировании это снижение составляет лишь 48,4\%. Кроме того, определено, что популяции патогенных бактерий в субстрате также сократились на 70,7-92,9\%. Указывается, что снижение содержания антибиотиков и ассоциированных бактерий в субстрате происходит за счет прохождения помета через кишечник и разложения кишечными микроорганизмами личинок [57]. В частности, выявлено снижение концентрации тетрациклина в переработанном личинками $H$. illucens помете кур на 97\% после 12 дней культивирования [58].

При начальных концентрациях окситетрациклина в субстрате 100, 1000 и 2000 мг/кг степень разложения этого антибиотика при выращивании личинок черной львинки составила 82,7; 77,6 и 69,3\% соответственно; в отсутствие личинок $H$. illucens данный показатель находился в пределах 19,3-22,2\% [59].

Выявлено, что доминирующими в кишечнике личинок являются представители Proteobacteria, а также Firmicutes и Bacteroidetes. После развития на курином помете доля протеобактерий в кишечнике личинок значительно сокращается, а доля Bacteroidetes значительно увеличивается. Сообщалось также, что в сравнении с бактериальным сообществом исходных личинок в кишечнике личинок $H$. illucens после их выращивания на курином помете наблюдалось порядка 90 новых родов микроорганизмов [60].

Исследования состава нативного и переработанного с помощью личинок черной львинки помета кур показали, что личинки разлагают карбоновые кислоты, спирты и алифатические компоненты, входящие в состав помета. Выявлено, что часть органических 
веществ разлагаются в результате метаболизма в кишечнике личинок $H$. illucens и превращаются в гуминоподобные вещества. Сообщалось, что степень гумификации перевариваемых органических соединений в курином помете составляет 42,45\% [61].

Как говорилось выше, биокомпост из куриного помета после выращивания на нем личинок $H$. illucens возможно использовать в качестве удобрения для выращивания различных сельскохозяйственных культур и домашних цветов. В частности, показано, что добавление в почву 10\% такого биокомпоста способствует лучшему росту стручкового перца (Capsicum annuum L.) по сравнению с грунтом с добавлением 15\% органического удобрения [62]. Биокомпост, полученный после переработки куриного помета с добавлением шабазита [53], предлагается в качестве основной среды для выращивания в почве на основе торфа салата-латука (Lactuca sativa L.).
Кроме того, сообщалось, что личинки H. illucens при выращивании на курином помете снижают выбросы всех летучих соединений более чем на 87\%; полное снижение выбросов наблюдалось для пропионовой кислоты и 2-метилфенола в результате их биоконверсии [63].

Муку из личинок и предкуколок черной львинки возможно использовать в качестве высокобелковой добавки в рационы домашних животных [64], птицы [65], рыб в аквакультуре [66,67].

Таким образом, обзор опубликованных данных показывает, что культивирование личинок мухи $H$. illucens способствует уменьшению объема помета и производству биомассы личинок с высоким содержанием белков и жирных кислот. Выявлено, что образующийся при этом биокомпост может использоваться в качестве ценного удобрения для выращивания сельскохозяйственных растений. Выращивание личинок черной львинки, кроме того, снижает содержание в помете некоторых металлов, антибиотиков и патогенных микроорганизмов, а также уменьшает его негативное воздействие на окружающую среду, по сравнению с компостированием и другими технологиями переработки, за счет снижения эмиссии в атмосферу летучих соединений.

\footnotetext{
Работа Быполнена ири финансобой поддержке Министерства науки и бистего образования РФ 6 рамках соглашения № 075-11-2019-070 om 29.11.2019.
}

Список литературы предоставляется авторами по запросу.

Для контакта с авторами:

Свергузова Светлана Васильевна

E-mail: pe@intbel.ru

Шайхиев Ильдар Гильманович

E-mail: ildars@inbox.ru

Сапронова Жанна Ануаровна

E-mail: sapronova.2016@yandex.ru

Бомба Илья Васильевич

E-mail: Ilya.bomba86@gmail.com

\title{
The Processing of Chicken Manure by the Larvae of Black Soldier Fly (Hermetia illucens): A Review
}

\author{
Sverguzova S.V.' ${ }^{1}$ Shaikhiev I.G. ${ }^{2}$, Sapronova J.A. ${ }^{1}$, Bomba I.V. ${ }^{1}$ \\ 'Belgorod State Technological University of V.G. Shukhov; \\ ${ }^{2}$ Kazan National Research Technological University
}

\begin{abstract}
Summary: The available published data on the use of the larvae of black soldier fly (Hermetia illucens) for the processing of poultry manure are briefly summarized. The data on the composition and increasing abundance of chicken manure are presented. Various technologies of the processing and utilization of manure are listed including bioconversion by larvae of various insects. The advantages of the larvae of H. illucens are presented. The life cycle of the insect and its phases are briefly described; the chemical composition of larval biomass is characterized. The composition of the manure of chicken, swine, and cattle as the substrates for this insect are compared, the advantages of chicken manure are highlighted; the efficiency of cultivation of $H$. illucens larvae on these substrates is compared. Bioconversion of chicken manure by the larvae was found to reduce the residual amounts of antibiotics, heavy metals, and pathogenic microorganisms in the resulting bio-compost and to reduce the emission of volatile compounds into the environment. The bio-compost is recommended to be used as a fertilizer for growing crops and flowers; the larval biomass can be used as protein-rich feed additive for poultry.
\end{abstract}

Keywords: chicken manure, processing, black soldier fly (Hermetia illucens), larvae, bioconversion. 